\title{
DIAMOND INCLUSIONS FROM SNAP LAKE, NWT CANADA
}

\author{
Prinya Promprated ${ }^{1}$, Lawrence Taylor ${ }^{1}$, Christine Floss ${ }^{2}$, Vladimir Malkovets ${ }^{1}$, Mahesh Anand ${ }^{1}$, \\ William Griffin $^{3}$, Nikolai Pokhilenko ${ }^{4}$, and Nikolai Sobolev ${ }^{4}$; \\ ${ }^{1}$ Planetary Geosciences Institute, Dept. of Geological Sciences, Univ. of Tennessee, Knoxville, TN 37996; ${ }^{2}$ McDonnell \\ Center of Space Science, Washington Univ., St. Louis, MO 63130; ${ }^{3}$ GEMOC National Key Centre, School of \\ Earth Sciences, Macquarie University, NSW 2109, Australia; ${ }^{4}$ Inst. of Mineralogy and Petrography, \\ Russian Academy of Sciences, Novosibirsk 630090 Russia
}

\section{INTRODUCTION}

Within the last decade, the Slave craton of Canada has been recognized for its diamond potential, with the discovery of diamondiferous kimberlites in the Lac de Gras area (Pell, 1997). Over 150 kimberlite pipes were subsequently identified, some with great potential for diamond-bearing. The scientific interest resulting from these discoveries has addressed the mantle beneath this Slave craton, from studies on a variety of samples that include mantle xenoliths and megacrysts, as well as diamonds and their mineral inclusions (DIs). However, with limited samples available, a relatively small number of studies have been carried out thus far.

Kimberlites of the Snap Lake area, NWT, situated in the SE portion of the Slave craton (Fig. 1), are diamond-bearing, and arguably the largest diamond deposit yet discovered on the North American continent (Pokhilenko et al., 2001). Previous study on the diamonds and their inclusions from this deposit revealed that the DI population is overwhelmingly dominated by ultramafic paragenesis $(95 \%$; Pokhilenko, 2001), of which the majority of DIs are olivine and enstatite, with small numbers of pyrope, chromite, clinopyroxene, and sulfide. The DIs of eclogitic paragenesis $(5 \%)$ include garnet and clinopyroxene. Preliminary EMP data suggest the high-pressure origin of some diamonds, as indicated by majoritic components in garnet and the presence of $\mathrm{K}_{2} \mathrm{O}$-rich clinopyroxene (Pokhilenko et al., 2001).

In the present study, we have performed major and trace-element analyses on the DIs in selected Snap Lake diamonds. In particular, diamonds with multiple inclusions were specially selected for study. This approach enables us to reconstruct the evolutionary history of diamond formation. Most studied DIs were extracted from the host diamonds using a conventional burning technique. Additional DIs were investigated in-situ, in order to relate their chemistry with respect to their locations within the host diamonds.

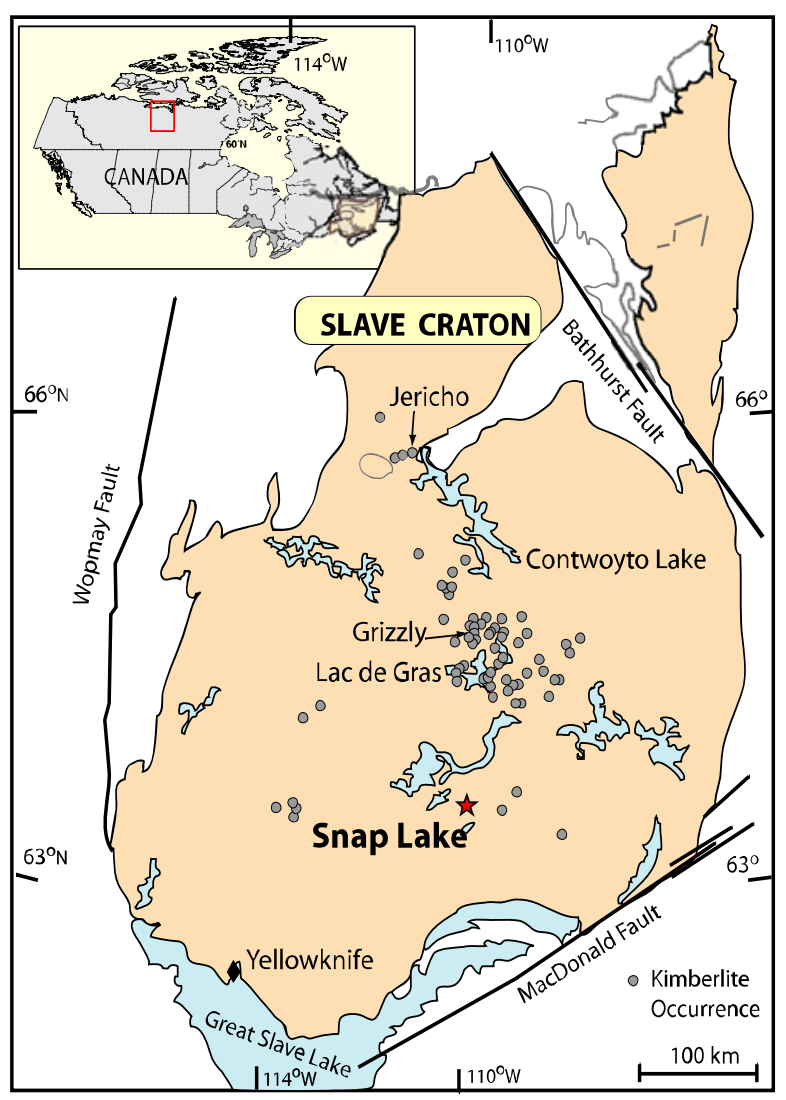

Figure 1: Simplified map of the Slave craton showing occurrences of kimberlites. Snap lake area is indicated by a star.

\section{DIAMOND INCLUSION CHEMISTRY}

\section{Garnet}

Three diamonds with multiple garnet inclusions were selected for detailed study. Diamond SL5-6/00 contains five eclogitic garnets with low $\mathrm{Cr}_{2} \mathrm{O}_{3}$ and $\mathrm{CaO}$ contents (0.07-0.11 and 3.14-3.34 wt\%, respectively; Fig. 2), and moderate $\mathrm{P}_{2} \mathrm{O}_{5}(0.07-0.08 \mathrm{wt} \%)$. These eclogitic garnets $\left(\mathrm{Pyr}_{59.6-60.6} \mathrm{Grs}_{8.2-8.8}\right)$ are classified as group B (Coleman et al., 1965), partly because of the composition of clinopyroxene (see below), found in the 
same diamond. It is noted that these garnet DIs contain slight excess in silica (i.e., majoritic component), ranging from 3.023-3.041 $\mathrm{Si}$ (p.f.u.), suggesting their high-pressure history.

Harzburgitic garnets occur in the rest of the studied diamonds, with 2 inclusions in SL3-31/00 and 3 in SL3$3 / 00$. The harzburgitic garnets in diamond SL3-31/00 contain slightly higher concentrations of $\mathrm{Cr}_{2} \mathrm{O}_{3}$ and $\mathrm{CaO}$ than those in SL3-3/00 (Fig. 2), but significantly higher in $\mathrm{P}_{2} \mathrm{O}_{5}$ contents (0.14-0.15 vs. 0.03-0.04 wt\%). Furthermore, the highest $\mathrm{Si}$ excess (3.050-3.072 p.f.u.) is observed in garnets of SL3-31/00, while "normal" $\mathrm{Si}$ contents occur in SL3-3/00.

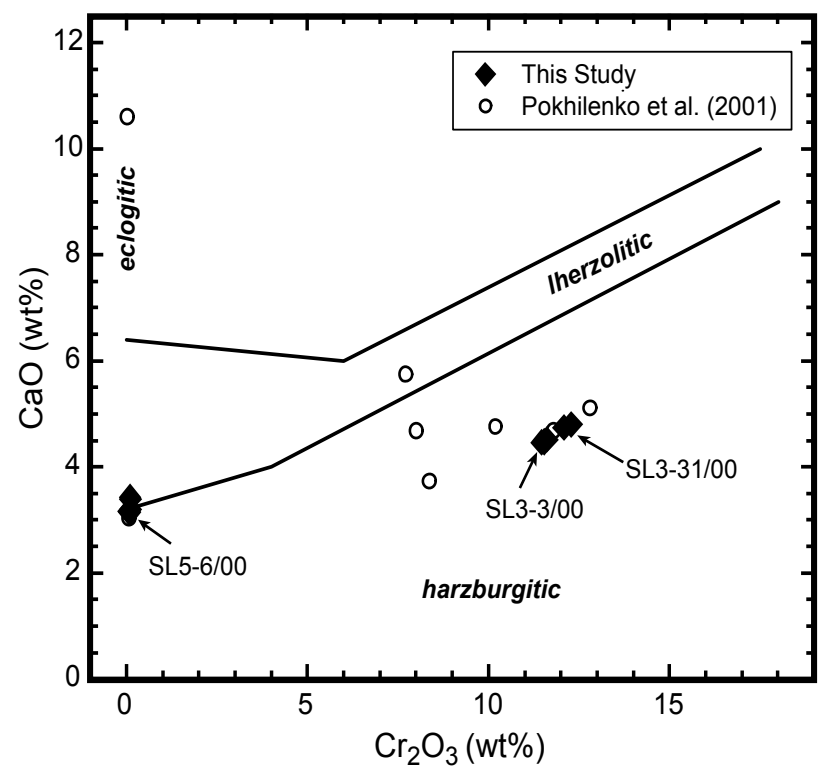

Figure 2: Compositions of the garnet diamond inclusions from Snap Lake kimberlite.

Garnet rare-earth-element (REE) concentrations, normalized to chondrite, are depicted in Fig. 3. LREEdepleted patterns with steep positive slopes (Fig. 3A) are observed in all eclogitic garnets of diamond SL5$6 / 00$. In contrast, harzburgitic garnets show the typical sinusoidal REE patterns, peaking at $\mathrm{Nd}$ and reaching the minima at Ho or Er (Fig. 3B). Garnets in diamond SL3-31/00 are distinctly more enriched in the REEs (up to an order magnitude), compared to those in SL3-3/00, and have the patterns similar to the Cr-rich pyrope megacrysts of the same area (Pokhilenko et al., 2001). Noteworthy is that the REE-enriched garnet DIs also posses excess $\mathrm{Si}$ and high $\mathrm{P}_{2} \mathrm{O}_{5}$, as mentioned above. In general, the major and REE concentrations among the DIs within the same diamonds only vary slightly.

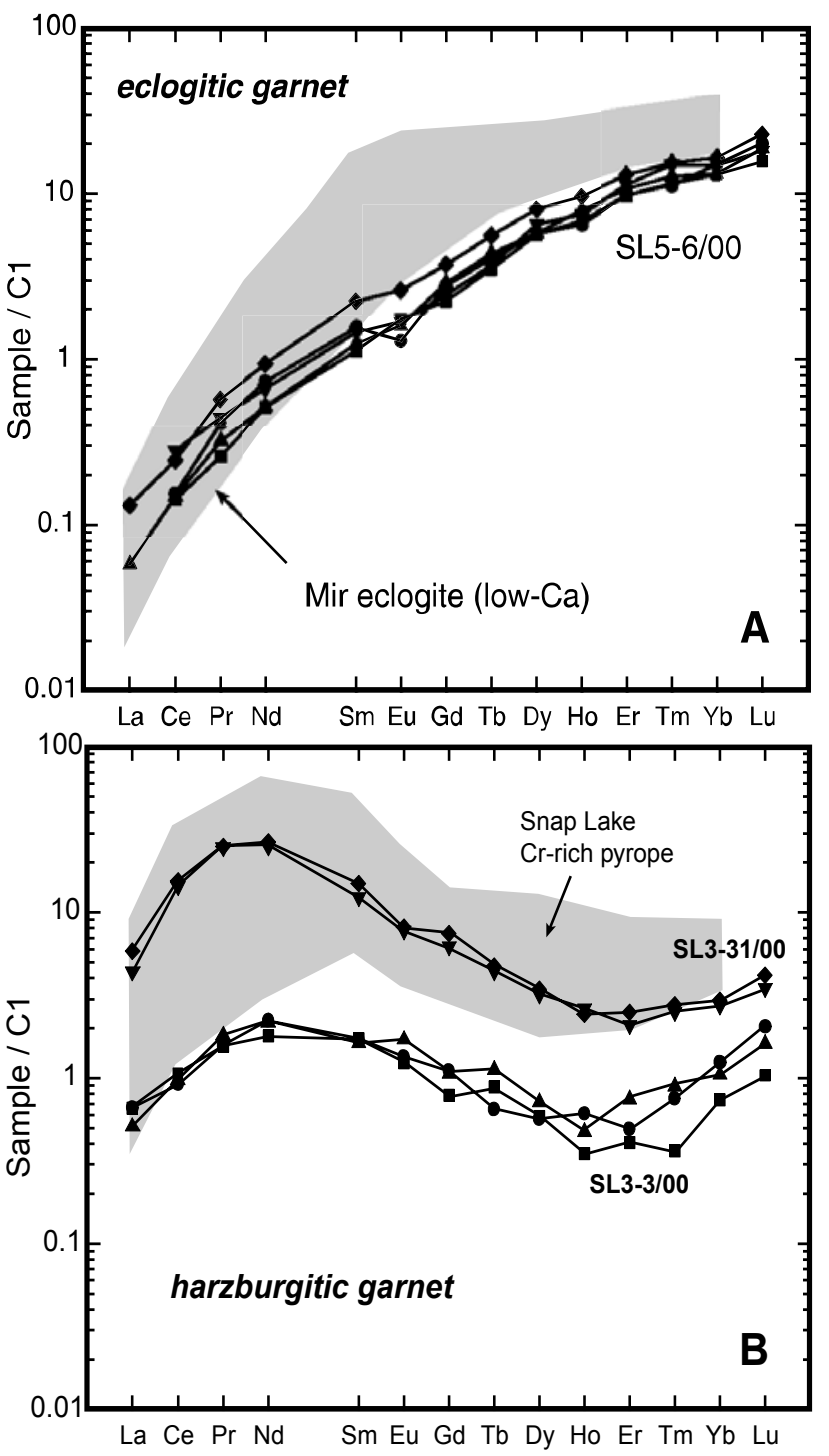

Figure 3: Chondrite-normalized REE patterns of eclogitic (A) and harzburgitic (B) garnet diamond inclusions from the Snap Lake kimberlite. Shaded area in A represents the REE patterns of low-Ca eclogitic garnets (Beard et al., 1996), and that in B is of pyrope megacrysts in Snap Lake kimberlite (Pokhilenko et al., 2001).

\section{Clinopyroxene}

Compositions of four clinopyroxene DIs correspond to Group B eclogites (Fig. 4), suggesting a possible crustal origin. Significantly high $\mathrm{K}_{2} \mathrm{O}$ contents (1.39 and 1.45 $\mathrm{wt} \%$ ) are observed in the two $\mathrm{Cpx}$ inclusions of diamond SL5-52/00. Lower $\mathrm{K}_{2} \mathrm{O}$ contents are seen in Cpx of two other samples: $0.50 \mathrm{wt} \%$ in SL3-32/00 and $0.17 \mathrm{wt} \%$ in SL5-6/00. $\mathrm{CaO}$ contents in these pyroxenes appear to follow $\mathrm{K}_{2} \mathrm{O}$, being the highest in SL5-52/00 (14.3 and $14.5 \mathrm{wt} \%)$ and lower in the remaining samples (12.1 and $9.66 \mathrm{wt} \%$, resp.). 


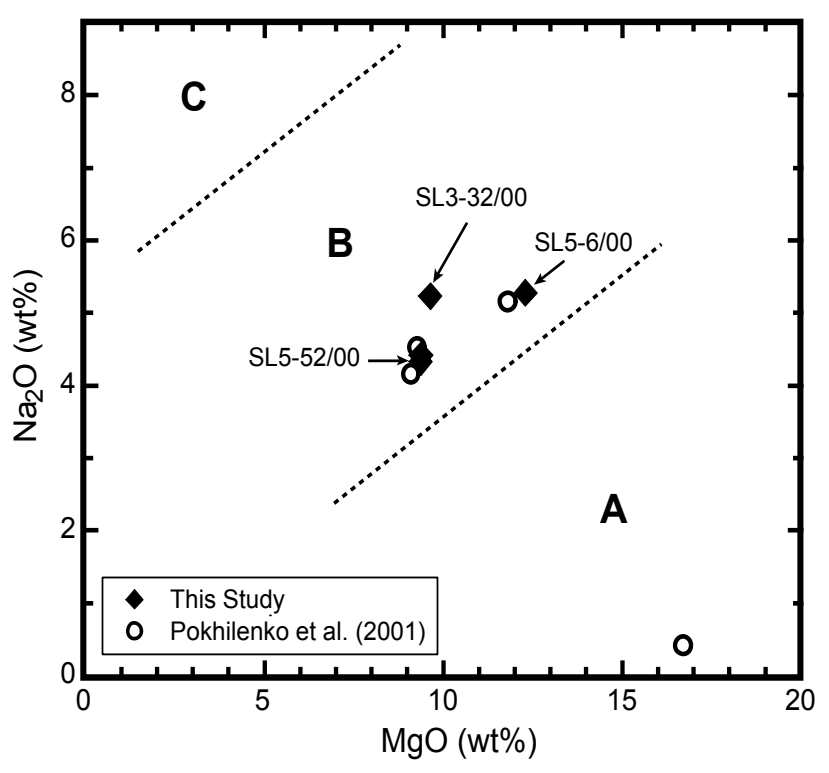

Figure 4: Compositions of clinopyroxene DIs from the Snap Lake area. All Cpxs belong to Group B eclogite.

REE patterns (chondrite normalized) of the Cpx inclusions can also be divided into two groups, following the major-element chemistry. That is, high$\mathrm{K}_{2} \mathrm{O}$ Cpx inclusions are enriched in LREE, with the peaks at Pr (Fig. 5A), where as the Cpxs with lower $\mathrm{K}_{2} \mathrm{O}$ are also lower in the light and medium REEs, with slight negative slopes towards the HREEs. The spike at $\mathrm{Tm}$ in Fig. 5A is possibly due to its low abundance, approaching the detection limit, whereas the Ce spike in Fig. 5B may be an artifact of weathering. The REE patterns of Snap Lake Cpx DIs are comparable to the Cpx in eclogite xenoliths from Mir.

\section{Orthopyroxene}

A total of 13 orthopyroxene inclusions from six diamonds were analyzed. Similar compositions were observed among the Opxs, which also have almost constant $\mathrm{Mg} \#$ (93.2-93.6) and a narrow range of $\mathrm{Ni}$ contents (837-1033 ppm). However, two distinct groups of Opx are observed: the high $\mathrm{Cr}(>2300 \mathrm{ppm})$ and the low $\mathrm{Cr}(<2000 \mathrm{ppm})$ groups (Fig. 6). The high$\mathrm{Cr}$ orthopyroxenes could be the result of equilibrium with chromites or Cr-rich garnets.

\section{Olivine - In-situ Analysis}

Two, relatively large $(\sim 200 \mu \mathrm{m})$ olivine inclusions occur in diamond SL5-62, which has been polished for in-situ analysis. The diamond (2.8 $\mathrm{mm}$ across) has
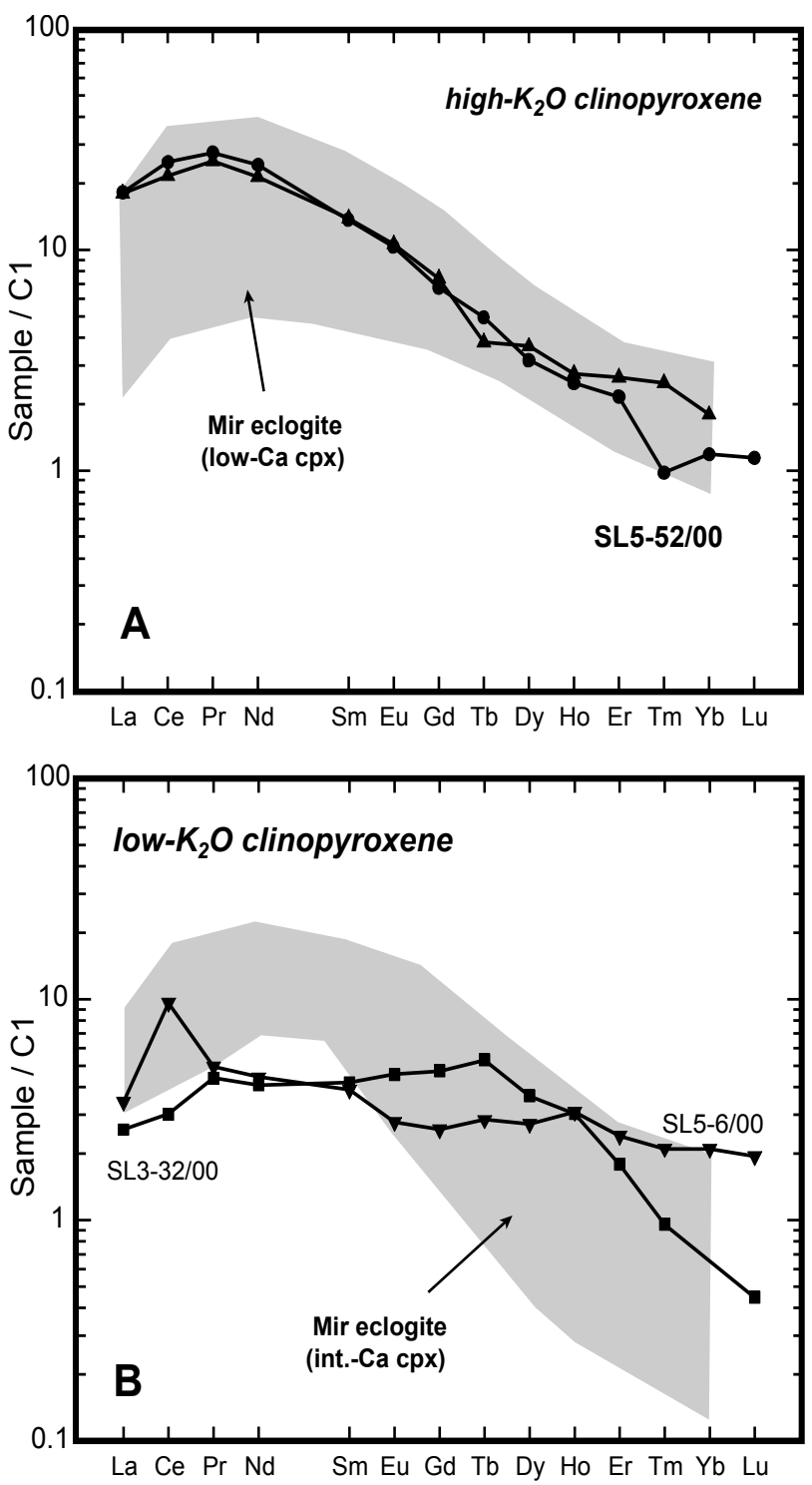

Figure 5: REE patterns of clinopyroxene DIs from the Snap Lake area. Clinopyroxene of selected Mir eclogite xenoliths are plotted for comparison (Beard et al., 1996).

flattened octahedral shape with mild resorption on the surface. Cathodoluminescence (CL) image of a polished surface (parallel to a (110) plane) revealed that the two olivines occur in two distinct growth zones within the diamond (Fig. 7). Well-defined stratigraphy of the diamond is clearly visible; however, at the immediate regions surrounding the inclusions, the growth zones are obscured, displaying hazy haloes. 


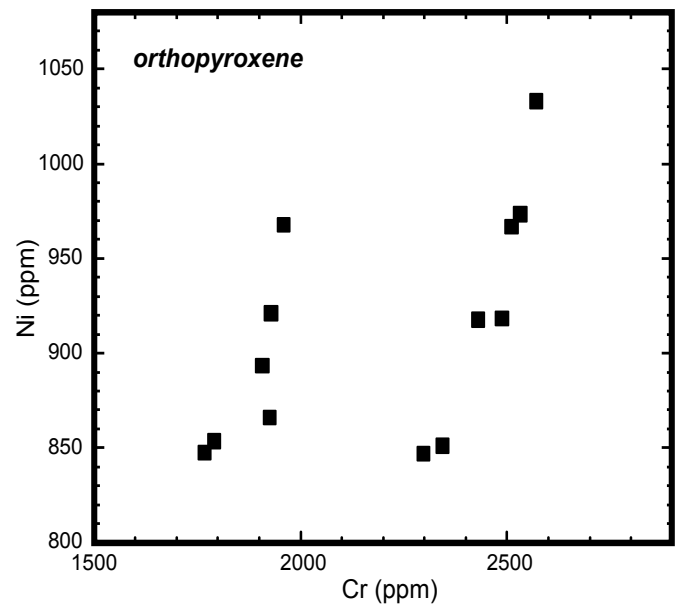

Figure 6: Plot of $\mathrm{Cr}$ vs Ni in orthopyroxene DIs from Snap Lake diamonds, showing two distinct groups of the Opx DIs.

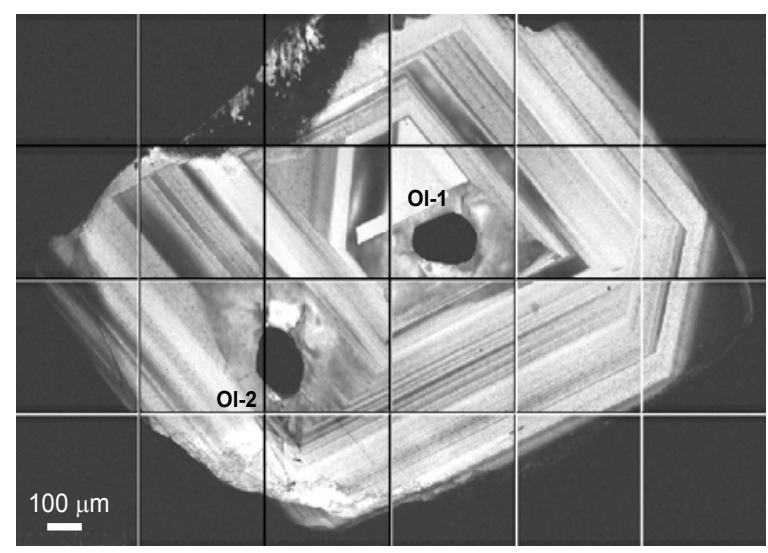

Figure 7: CL image of diamond SL5-62, showing two olivine inclusions in the core (Ol-1) and rim (Ol-2) zones.

\section{Table 1: Trace-element compositions of olivine inclusions (ppm)}

$\begin{array}{lll} & \text { Ol-2 (rim) } & \text { Ol-1 (core) } \\ \mathrm{Ni} & 2391 & 2389 \\ \mathrm{Cr} & 351 & 572 \\ \mathrm{Ca} & 320 & 281 \\ \mathrm{Sc} & 0.64 & 0.44 \\ \mathrm{Ti} & 6.75 & 4.83 \\ \mathrm{Sr} & 1.16 & 0.46 \\ \mathrm{Zr} & 0.56 & 0.35 \\ \mathrm{Ba} & 1.11 & 0.75 \\ \mathrm{Fo} & 92.1 & 92.2\end{array}$

As demonstrated in Table 1, the compositions of the two olivines are comparable with respect to $\mathrm{Fo}$ and $\mathrm{Ni}$ contents. However, $\mathrm{Cr}$ decreases from Ol-1 to Ol-2 (i.e., core to rim), whereas incompatible elements consistently increase.

\section{DISCUSSION}

\section{Evolution of C-bearing Fluids}

Chemistry of DIs that occur in different growth zones provides detailed insights into the growth history of diamond. The systematic chemical variations among multiple inclusions within the same diamonds usually involve changes in P-T-X conditions. Bulanova et al. (1988) believed that the small decrease of Escola molecule $\left(\mathrm{Ca}_{0.5} \mathrm{AlSi}_{2} \mathrm{O}_{6}\right)$ in clinopyroxene and $\mathrm{X}_{\mathrm{Ca}}$ in garnet from core to rim of the eclogitic diamonds from Yakutia was due to a small increase in pressure during diamond growth. In a study of a Mir diamond with multiple inclusions, Taylor et al. (1998) showed that $\mathrm{MgO}$ and $\mathrm{TiO}_{2}$ as well as LREEs increase in the Cpx inclusion in the rim compared to that in the core. They interpreted that as a result of metasomatic processes, which were concomitant with the decrease in temperature (i.e., 1250 to $1190^{\circ} \mathrm{C}$ from core to rim), based on the total $\mathrm{N}$ contents and $\mathrm{N}$-aggregation states of the host diamond.

In this study, the two olivine inclusions that occur in Snap Lake diamond SL5-62 (Fig. 7) practically have identical Fo and Ni contents, suggesting that they were at the same equilibrium conditions prior to encapsulation by the host diamond. Therefore, the differences in incompatible elements between the two olivines are likely to be the effect of processes involving in the diamond formation, particularly the metasomatic reaction between the olivines and $\mathrm{C}$ bearing fluids. These fluids, which precipitated diamond, most probably evolved as the diamond grew, resulting in changes in $\mathrm{N}$-contents, visible as different growth layers, and the increase in incompatible elements observed in Ol-2 at rim.

\section{P-T State of Snap Lake Diamonds}

The presence of majorite components, as indicated by excess in silica, in garnets DIs has been used to estimate the pressure of diamond formation. This is on the basis that at pressures $>5 \mathrm{GPa}$, garnet becomes Aldeficient, and, therefore, $\mathrm{Si}$ can substitute into the octahedral site, resulting in the silica excess (Moore and Gurney, 1985). In diamond SL5-6/00, eclogitic garnets contain Si of $\sim 3.041$ (p.f.u.), consistent with pressure of $\sim 60 \mathrm{kbar}$ (Irifune, 1987) or at depths around $180 \mathrm{~km}$. If it can be assumed that clinopyroxene in this sample was in equilibrium with these garnets, the temperature estimate is $\sim 1255{ }^{\circ} \mathrm{C}$. These estimates are consistent with pressure obtained from the $\mathrm{Al}_{2} \mathrm{O}_{3}$ contents in 
orthopyroxene DIs of the present study, and are in agreement with the estimates obtained from eclogite xenoliths from the Lac de Gras area (Griffin et al., 1999).

The harzburgitic garnet DIs in diamond SL3-31/00 contain even higher amounts of excess silica (3.0503.072 p.f.u.), yielding pressure approximately $65-75$ kbar $(195-225 \mathrm{~km})$. This is in agreement with their Crrich nature, which is also pressure dependent (Stachel and Harris, 1997). Clinopyroxene inclusions in diamond SL5-52/00 contain unusually high $\mathrm{K}_{2} \mathrm{O}$ contents, reaching $1.45 \mathrm{wt} \%$. Such a high uptake of $\mathrm{K}_{2} \mathrm{O}$ by a Cpx was experimentally determined to occur at $10 \mathrm{GPa}$ (Harlow, 1997), translated to the depth of $300 \mathrm{~km}$.

\section{Diamond Source of the SE Slave Craton}

The unique feature of the Slave craton is its mineralogical and chemical stratification. Kopylova and Russell (2000) showed that the mantle beneath the Jericho kimberlite (northern Slave craton) consist of depleted sp-peridotite at a depth of 80-100 km, garnet peridotite up to $200 \mathrm{~km}$, and fertile-garnet peridotite and pyroxenite-rich layers at greater depths. Griffin et al. (1999) suggested similar stratigraphy of the central Slave craton beneath Lac de Gras area that is depleted (mainly harzburgite) in the shallower depths and becomes fertile (mainly lherzolite) at deeper levels.

The depth range obtained from the Snap Lake DIs, along with the high proportion of peridotitic diamond inclusions, suggests that the majority of Snap Lake diamonds derived from the upper horizon, dominated by harzburgitic lithology. However, some eclogitic diamonds may have been transported from an unusually great depth $(300 \mathrm{~km})$. Griffin et al. (1999) proposed a model that involves subduction of oceanic lithosphere to form upper depleted layer, followed by the rising of a "super plume" from the lower mantle. This superplume, perhaps, lies directly beneath the central Slave craton, as evidenced by the occurrence of diamonds of superdeep paragenesis (Davies et al., 1998) and the high concentrations of kimberlite in the Lac de Gras area. If so, the southern flank of this plume may have extended into the Snap Lake area, thereby providing a mechanism that has brought up some unusually deep diamonds to the surface.

\section{REFERENCES}

Beard, B.L., Fraracci, K.N., Taylor, L.A., Snyder, G.A., Clayton, R.A., Mayeda, G.A., and Sobolev, N.V., 1996.
Petrography and geochemistry of eclogites from Mir kimberlite, Yakutia, Russia. Contrib. Mineral. Petrol., 125, 293-310.

Bulanova, G.P., Novgorodov, P.G., and Palova, L.A., 1988. A first find of melt inclusion in diamond from Mir pipe. Geokhimiya, 5, 756-765 (In Russian).

Coleman, R.G., Lee, E.D., Beaty, L.B., and Brannock, W.W., 1965. Eclogites and eclogites: Their differences and similarities. GSA Bull., 76, 483-508.

Davies, R., Griffin, W.L., Pearson, N.J., Andrew, A., Doyle, B.J., and O'Reilly, S.Y., 1998. Diamonds from the Deep: Pipe DO-27, Slave Craton, Canada. Proc. of the $7^{\text {th }}$ Int. Kimberlite Conf., v.1, pp 148-155.

Griffin, W.L., Doyle, B.J., Ryan, C.G., Pearson, N.J., O'Reilly, S.Y., Davies, R., Kivi, K., Van Achterbergh, E., and Natapov, L.M., 1999. Layered mantle lithosphere in the Lac de Gras area, Slave craton: Composition, structure and origin. J. Petrol., 40, 705-727.

Harlow, G.E., 1997. K in clinopyroxene at high pressure and temperature: An experimental study. Am. Min., 82, 259269.

Irifune, T., 1987. An experimental investigation of the pyroxene garnet transformation in a pyrolite composition and its bearing on the constitution of the mantle. Physics of the Earth and Planetary Interiors, 45, 324-336.

Kopylova, M.G. and Russell, J.K., 2000. Chemical stratification of cratonic lithosphere: Constraints from the northern Slave craton, Canada. EPSL, 181, 71-87.

Moore, R.O. and Gurney, J.J., 1985. Pyroxene solid solution in garnets included in diamond. Nature, 318, 553-555.

Pell, J.A., 1997. Kimberlites in the Slave craton, NWT, Canada: A preliminary review. Russian Geology and Geophysics, 38, 5-16.

Pokhilenko, N.P., Sobolev, N.V., McDonald, J.A., Hall, A.E., Yefimova, E.S., Zedgenizov, D.A., Logvinova, A.M., and Reimers, L.F., 2001. Crystalline inclusions in diamonds from kimberlites of the Snap Lake area (Slave Craton, Canada): New evidences for the anomalous lithospheric structure. Doklady Earth Sci. 380, 806-811.

Stachel, T. and Harris, J.W., 1997. Diamond precipitation and mantle metasomatism-evidence from the trace element chemistry of silicate inclusions in diamonds from Akwatia, Ghana. Contrib. Mineral. Petrol., 129, 143-154.

Taylor, L.A., Milledge, H.J., Bulanova, G.P., Snyder, G.A., and Keller, R.A., 1998. Metasomatic Eclogitic Diamond Growth: Evidence from multiple inclusions. Inter. Geol. Rev., 40, 663-676.

Contact: P Promprated, 306 Geological Sciences Bldg., The Univ. of Tennessee, Knoxville, TN 37996, USA, E-mail: prinya@utk.edu. 